\title{
SOCIAL MEDIA MARKETING; STRATEGI KOMUNIKASI BISNIS ERA DIGITAL \\ (Studi Analisis Portal TaniFund.com)
}

\author{
Mellyan \\ STAIN Teungku Dirundeng Meulaboh \\ E-mail: mellyancutkeumalanyakman@gmail.com
}

\begin{abstract}
Abstrak
Dunia digital dengan segala kebaharuannya membawa perubahan pada setiap bidang. Hal tersebut dipicu oleh munculnya teknologi internet. Berbagai sektor beradaptasi dengan kemunculan teknologi tersebut, salah satu nya dunia bisnis. Jika dua dekade sebelumnya dunia bisnis masih lazim menggunakan metode tradisional, kini dunia bisnis menggunakan media digital termasuk media sosial di dalamnya untuk promosi dan mengembangan bisnis. Tanifund merupakan salah satu platform pendanaan finansial yang fokus pada pertanian, peternakan, dan perikanan. Menarik mengkaji Tanifund karena terdapat perbedaan besar pertanian era digital yang "memindahkan" lahan pertanian dalam dunia digital dan era tradisional yang menganggap pertanian merupakan pekerjaan berat yang hanya dilakukan di lahan terbuka. Metode penelitian ini menggunakan penelitian kualitatif, library research (penelitian pustaka) dengan pendekatan deskriptif analisis. Hasil penelitian menunjukkan Tanifund telah memanfaatkan media sosial untuk promosi dan pengembangan bisnis, hanya saja belum dilaksanakan dengan maksimal. Memaksimalkan penggunaan media sosial dapat meningkatkan jumlah maskarakat pengguna Tanifund. Dibutuhkan beberapa treatment dan tim yang solid untuk menggerakkan media sosial menjadi media promosi dan pengembangan bisnis.
\end{abstract}

Kata Kunci: Tanifund, Sosial Media, Komunikasi Bisnis, Era Digital

\begin{abstract}
The digital world with all its novelty brings changes in every field. This was triggered by the advent of internet technology. Various sectors adapt to the emergence of the technology, one of the business. At the previous two decades, business world is still prevalent using traditional methods, now the business world uses digital media, including social media in it for promotion and business development. Tanifund is a financial funding platform that focuses on agriculture, animal husbandry, and fisheries. It is interesting to study Tanifund because there are big differences in the era of digital agriculture that "move" agricultural land in the digital world and the traditional era which considers agriculture is a heavy work that is only done in open land. This research method uses qualitative research, library research with a descriptive analysis approach. The results of the research show Fanifund has utilized social media for business promotion and development, it's just not been implemented to the maximum. Maximizing the use of social media
\end{abstract}


can increase the number of people who use tanifund. It takes several treatments and a solid team to move social media into media promotion and business development.

Keywords: Tanifund, Social Media, Business Communication, Digital Era

\section{PENDAHULUAN}

Teknologi telah menjadikan dunia seakan tanpa sekat, teknologi berbasis internet menjadi pemicunya. Secara garis besar, kemajuan teknologi internet juga disertai dengan berkembangnya berbagai titik akses (access point) yang membawa dampak pada percepatan globalisasi industri. Teknologi digital yang sangat luas penerapannya berdampak pada setiap bidang, termasuk sektor bisnis. Kegiatan bisnis yang mulanya merupakan interaksi antara para pengusaha dan konsumen dengan sistem tradisional, dituntut mengikuti perkembangan bisnis di era digital dengan segala kebaharuannya.

Dengan berbagai kemudahan komunikasi melalui internet, menjadikan semua entitas di dalam sistem industri tidak lagi dibatasi ruang dan waktu. Hal tersebut membuat revolusi industri 4.0 berpengaruh pada cara industri beroperasi dan melayani konsumennya. Siap tidak siap industri bisnis harus beradaptasi. Karena di zaman serba digital, ukuran besar perusahaan tidak lagi menjadi jaminan, namun kelincahan perusahaan menjadi kunci keberhasilan meraih kesuksesan. ${ }^{1}$ Pesatnya perkembangan internet membawa peluang sekaligus tantangan bagi pemasaran konvensional. Dalam hal filosofi pemasaran, terjadi perubahan fokus yang berkaitan dengan produk, ukuran paras, alat kompetitif teknologi kunci dan ukurannya yang membedakan empat prespektif pemasaran utama. Internet juga menandai era baru pemasaran, yaitu era digital markting yang bercirikan:

a. Bermucnulannya born global. Dalam dua decade terakhir, semakin banyak perusahaan yang tidak mengikuti pola tahap-tahap tradisional dalam proses internasionalisasi. Perusahaan semacam ini menaegetkan pasar internasional/global sejak di dirikan.

${ }^{1}$ M. Ariza Eka Yusendra, Mendobrak Pola Konvensional Pengembangan Kewirausahaan Di Era Industri 4.0: Peningkatan Peranan Perguruan Tinggi Melalui Inkubator Bisnis Dan Teknologi, (Institut Informatika Bisnis Darmajaya: Prociding PKM-CSR Vol.2), 2019, hal 1 
b. Berakhirnya era "Push Strategy" konsumen memiliki daya tawar yang semakin kuat. Konsumen memiliki kekebasan memilih, sekaligus memegang kendali atas atas setiap informasi yang mereka terima.

c. Konsumen mengetahui fakat dan "kebenaran", akses terhadap internet berdampak terhadap konsumen menjadi "Perfectly informed". Berbagai situs dapat membantu pelanggan untuk memperoleh informasi.

d. Mass Customization, dalam era digital marketing, konsumen memungkinkanuntuk merancang produknya sendiri. Implikasinya setiap perusahaan harus mengalihkan fokus dari produk menjadi solusi atau saran pemecahan masalah konsumen. Konsumen membeli manfaat produk, tidak hanya produk itu sendiri.

e. Insignifikansi batas-batas geografis, ritel kini sudah tidak identic dengan lokasi.

f. Pelelangan produk online (everything is autioned), internet juga dimanfaatkan sebagai media pelelangan produk secara real-time, misalnya untuk tiket pesawat (priceline dan ebay).

g. Efek multiplier ekstrem. Berita akan menyebar dengan sangat cepat ke seluruh penjuru dunia.

h. Tumbuhnya komunitas online, komunitas biasanya terbentuk karena kesamaan minat, aktivitas dan opini, setiap anggota komunitas dapat berinteraksi tanpa dibatasi jarak dan waktu.

i. Manfaat dan peluang bisnis baru di cyberspace. Melalui digitalisasi pemasaran, telah banyak perusahaan yang memperoleh manfaat berupa efisiensi, efektivitas, penyempurnaan kualitas dan pendapatan. ${ }^{2}$

Penyebaran informasi merupakan salah satu point utama untuk pengembangan bisnis, salah satu yang menandai era digital adalah bermunculan berbagai platform media sosial, dalam dua dekade berbagai media sosial hadir mengakomodir kebutuhan dan keinginan masyarakat di antaranya facebook, twitter, Instagram, Pinterest, youtube dan sebagainya. Menurut Mandibergh 2012, media sosial adalah media yang mewadahi kerjasama di antara pengguna yang

${ }^{2}$ Fandi Tjiptono dan Gregorius Chandra, Pemasaran Global konteks Offline dan Online, (Yogyakarta: UPTT STIM YKPN), 2012, hal, 237 
menghasilkan konten (user-generated content). ${ }^{3}$ Kemunculan berbagai platform media sosial tersebut juga menciptakan iklim bisnis yang semakin dinamis. Berbagai bidang bisnis mulai menggunakan media sosial sebagai sarana promosi sekaligus pengembangan bisnis, termasuk bisang pertanian seperti yang dilakukan oleh Tanifund. Pertanian yang mulanya dianggap hanya dapat dilakukan dengan metode tradisional, perkembangan digital telah membawa perubahan yang tidak pernah terfikirkan oleh generasi sebelumnya, jika Bertani dapat dilakukan melalui media digital.

\section{LANDASAN TEORI}

Sistem komunikasi mampu mengubah kebudayaan, Harold Adams Innis, seorang ekonom Kanada yang menjadi teorisi ilmu komunikasi percaya bahwa ilmu komunikasi merupakan inti dari teknologi. ${ }^{4}$ Menurut Weber, kata sosial secara sederhana merujuk pada relasi sosial. Relasi sosial itu sendiri dapat dilihat dalam kategori aksi sosial (social action) dan relasi sosial (social relations). Kategori ini mampu membawa penjelasan tentang apa yang dimaksud dengan aktivitas sosial dan aktivitas individual. Definisi media sosial menurut Mandibergh 2012, media sosial adalah media yang mewadahi kerjasama di antara pengguna yang menghasilkan konten (user-generated content), Menurut Shirky (2008), media sosial dan perangkat lunak sosial merupakan alat untuk meningkatkan kemampuan pengguna untuk berbagi (to share), bekerjasama (to co-operate) di antara pengguna dan melakukan tindakan secara kolektif yang semuanya berada di luar kerangka institusional maupun organisasi. Boyd (2009) menjelaskan media sosial sebagai kumpulan perangkat lunak yang memungkinkan individu maupun komunitas untuk berkumpul, berbagi, berkomunikasi, dan dalam kasus tertentu saling berkolaborasi atau bermain. Media sosial memiliki kekuatan pada User-generated content (UGS) dimana konten dihasilkan oleh pengguna, bukan editor sebagaimana di institusi media massa. ${ }^{5}$ Oleh karena itu, media sosial dapat diartikan sebagai media yang dapat digunakan oleh seseorang ataupun kelompok untuk berinteraksi, bekerjsama,

3 Rulli Nasrullah, Media Sosial Perspektif Komunikasi, Budaya dan Sosioteknologi, (Bandung: Simbiosa Rekatama Media), 2016, hal 11.

${ }^{4}$ Rulli Nasrullah, Media Sosial Perspektif Komunikasi, Budaya dan,... hal 11

${ }^{5}$ Ibid. hal 12 
berkomunikasi dan membentuk ikatan sosial secara virtual.

Sebagaimana diketahui, media sosial merupakan salah satu platform yang muncul di media ciber. Karena itu, media sosial memiliki karakteristik yang tidak jauh berbeda dengan media siber. Namun, media sosial memiliki karakteristik khusus yang tidak dimiliki oleh jenis media siber lainnya. Terdapat ciri tertentu yang hanya dimiliki media sosial:

a. Jaringan (network)

b. Informasi (information)

c. Arsip

d. Interaksi

e. Simulasi sosial

f. Konten oleh pengguna ${ }^{6}$

Qmee, sebuah lembaga riset yang didirikan pada tahun 2020 oleh Nick Sutton dan Jonathan Knight, pada 2014 mempublikasikan infografik tentang apa yang terjadi dalam 60 detik di media sosial. Data menunjukkan bahwa terdapat 67 ribu foto yang diunggah di akun instragram, 433ribu teks (tweet) yang dipublikasi di twitter, dan 293 ribu status yang diperbaharui (update) di facebook. Jumlah tersebut hanya dala hitungan 60 detik dan semua itu tersimpan dalam arsip digital serta dapat diakses oleh siapapun. Julah tersebut tentu saja semakin meningkat setiap harinya.

Media sosial dianggap sebagai ruang perpustakaan virtual. Layaknya perpustakaan, di media sosial juga terdapat kode panggil atau kode rak buku sebagaimana di perpustakaan. Salah satunya menggunakan tagar atau tag. Aktivitas mentagar (tagging) ini untuk menandai topik yang sedang dibincangkan oleh pengguna. Jika melihat cara kerja di twitter, tagar bukan sekedar penanda topik, tetapi juga menjadi informasi seberapa besar topik tersebut diperbincangkan atau menjadi popular di dunia virtual. Interaksi dalam media sosial merupakan salah satu pembeda antara media lama (old media) dengan media baru (new media).

Dalam hal ini, Holmes menyatakan dalam media lama pengguna atau khalayak media merupakan khalayak yang pasif dan cenderung tidak mengetahui satu dengan lainnya. Sementara di media baru, pengguna dapat berinteraksi baik

\footnotetext{
${ }^{6}$ Opcit. hal 14
} 
antar pengguna maupun dengan prouser konten media. Gane dan Beer mengungkapkan secara teori kata interaksi merupakan proses yang terjadi di antara pengguna dan perangkat teknologi. Kehadiran teknologi dan perangkatnya telah menjadi bagian yang tidak dapat dilepaskan dari kehidupan sehari-hari. Bahkan telah menjadi sesuatu yang disebut "Digital technologi has become integral parts of our everyday lines". Perangkat teknologi telah meremediasi ke dalam ruang dan waktu, tempat kerja dan rumah sampai segala sisi kehidupan hingga terkadang tidak lagi dapat membedakan kehidupan nyata (offline) dan maya (online). ${ }^{7}$

Pada tahun 2014, data riset dari http://wearesocial.sg menunjukkan rata-rata pengguna masyarakat Indonesia menghabiskan waktu sekitar 3 jam untuk terkoneksi dan berselancar di media sosial. Sebagian dari pengguna tersebut mengakses media sosial menggunaka telepon pintar. ${ }^{8}$ Pada tahun 2020 , terjadi peningkatan terhadap penggunaan media sosial di Indonesia, penduduk Indonesia menghabiskan 3,24 jam berselancar di media sosial. Dari table grafik tersebut dapat dilihat, Indonesia menjadi negara kelima di dunia paling banyak menghabiskan waktu menggunakan media sosial. ${ }^{9}$

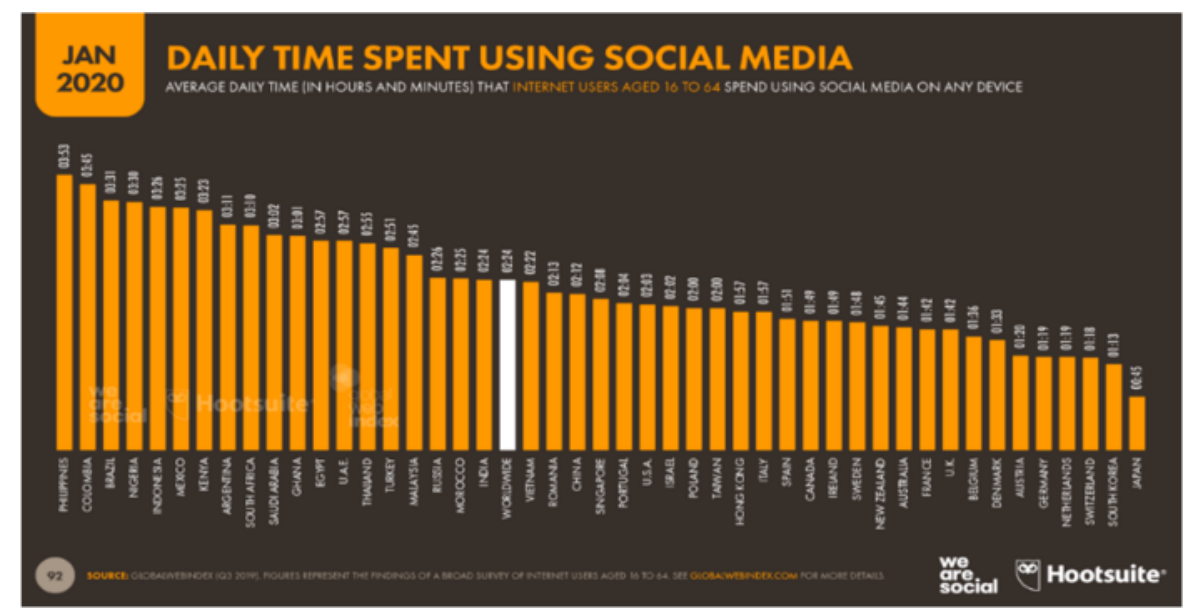

datareportal.com/reports/digital-2020-indonesia

Terdapat 175,4 juta pengguna internet di Indonesia pada Januari 2020. Jumlah pengguna internet di Indonesia meningkat 25 juta $(+17 \%)$ antara tahun

\footnotetext{
${ }^{7}$ Rulli Nasrullah, Media Sosial Perspektif Komunikasi, Budaya dan, ... hal 24

${ }^{8}$ Rulli Nasrullah, Media Sosial Perspektif Komunikasi, Budaya dan, ... hal 12

${ }^{9} \mathrm{https}$ ://datareportal.com/reports/digital-2020-indonesia, diakses pada 26 Juni 2020
} 
2019 dan 2020. Peningkatan pengguna internet di Indonesia mencapai 64\% pada Januari 2020. Sedangkan untuk Pengguna media sosial di Indonesia, terdapat 160,0 juta pengguna media sosial di Indonesia pada Januari 2020. Jumlah tersebut meningkat 12 juta $(+8,1 \%)$ antara April 2019 dan Januari 2020. ${ }^{10}$

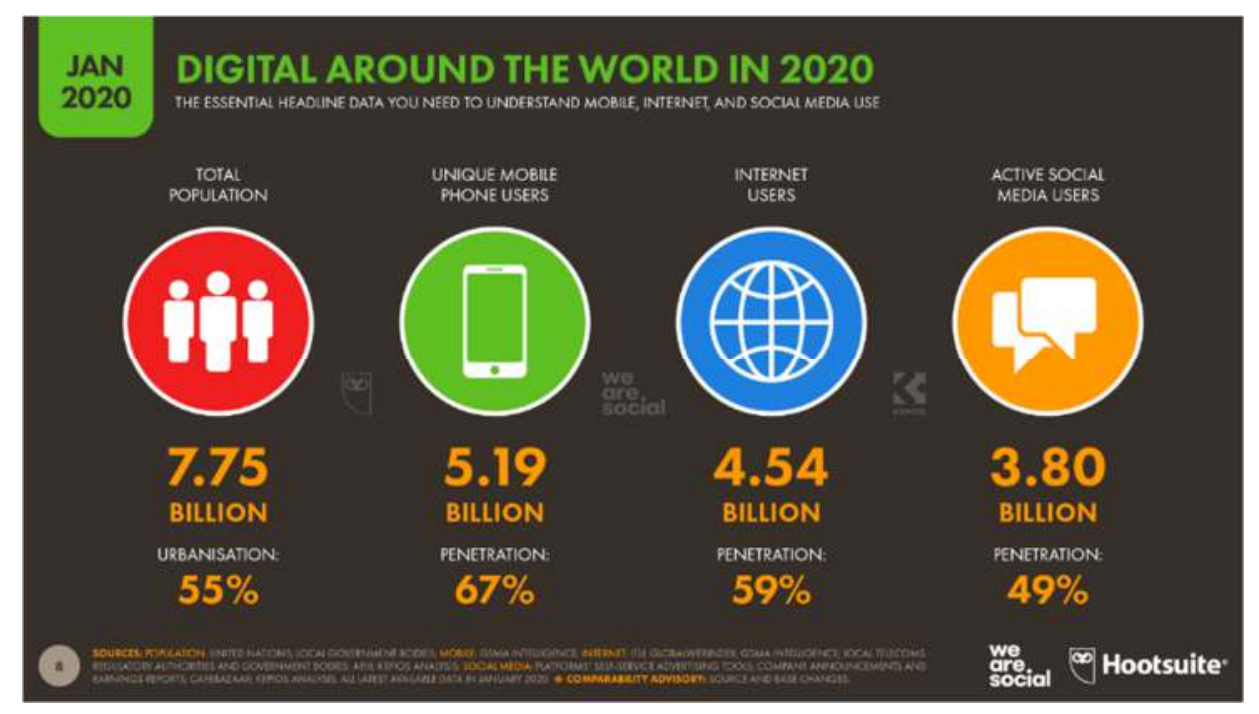

Di era digital, media sosial berperan penting dalam kehidupan manusia, 2020 lebih banyak orang menghabiskan lebih banyak waktu melakukan lebih banyak hal secara online daripada sebelumnya. Jumlah pengguna internet di seluruh dunia mencapai 4,54 miliar, meningkat 7 persen (298 juta pengguna baru) dibandingkan dengan Januari 2019. Di seluruh dunia, terdapat 3,80 miliar pengguna media sosial pada Januari 2020, jumlah ini meningkat lebih dari 9 persen (321 juta pengguna baru) disbanding tahun lalu. Secara global, lebih dari 5,19 miliar orang menggunakan ponsel, dengan jumlah pengguna naik 124 juta $(2,4$ persen) selama setahun terakhir. ${ }^{11}$

Jika menilik kerangkan awal penggunaan media sosial, dapat dilihat menggunakan perspektif konstruksi sosial, interaksi sosial merupakan landasan awal budaya maupun struktur sosial. Interaksi sosial merupakan landasan budaya maupun struktur sosial. Ketiga sisi model yaitu interaksi sosial, budaya maupun

\footnotetext{
${ }^{10} \mathrm{https}$ //datareportal.com/reports/digital-2020-indonesia diakses pada 26 Juni 2020

${ }^{11} \mathrm{https}$ //wearesocial.com/blog/2020/01/digital-2020-3-8-billion-people-use-socialmedia, diakses 26 Juni 2020
} 
struktur sosial pada akhirnya akan membentuk apa yang disebut dengan realitas sosial sebagai pusat.

\section{Gambar 1.1 Segitiga Realitas Sosial}

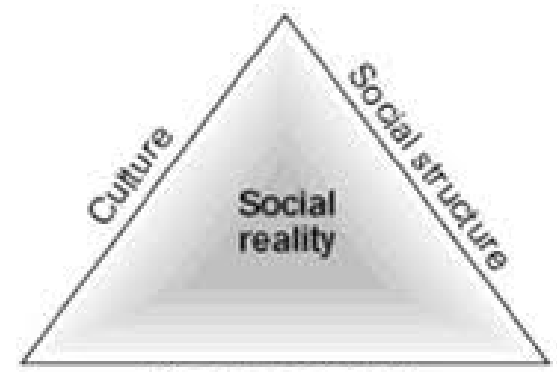

Social interaction

Gotved, S. 2006a. "The Construction of Cybersocial Reality,"

Terkait internet, Gotved menggunakan model segitiga tersebut untuk melihat bagaimana komunikasi online terjadi dan aspek-aspek yang muncul mengikutinya. Penggunaan teknologi mengubah realitas sosial yang dalam kondisi tertentu mengaburkan batasan-batasan yang ada di antara teknologi dan sosial. ${ }^{12}$

Kini, berbagai pihak memanfaatkan media sosial sebagai medium untuk transaksi bisnis. Termasuk yang dilakukan oleh Tanifund, kegiatan pertanian yang dianggap oleh banyak pihak merupakan pekerjaan berat dan sebagian besar menghabiskan tenaga dan dilakukan di alam terbuka. Dalam penelitian ini, akan membahas mengenai metode komunikasi bisnis yang dilakukan oleh Tanifund untuk menggerakkan bisnis mereka dan menjadi salah satu platform bidang pertanian terbaik yang dimiliki Indonesia sejauh ini. Jika diamati, Tanifund yang merupakan bagian dari Tani Group ini menggunakan sistem Peer to Peer Lending (P2P). Seperti dilansir oleh koinwork.com, P2P lending adalah praktik atau metode memberikan pinjaman uang kepada individu/bisnis dan juga sebaliknya; mengajukan pinjaman untuk keperluan individu/bisnis. Intinya, P2P Lending yaitu menghubungkan antara pemberi pinjaman (pendana/pendana) dengan peminjam secara online. Peer to Peer Lending memungkinkan setiap orang untuk memberikan pinjaman atau mengajukan pinjaman yang satu dengan yang lain untuk berbagai kepentingan tanpa menggunakan jasa dari lembaga keuangan yang

${ }^{12}$ Rulli Nasrullah, Media Sosial Perspektif Komunikasi, Budaya dan, ... hal, 53 
sah sebagai perantara. Pada dasarnya, sistem P2P Lending ini sangat mirip dengan konsep marketplace online, yang menyediakan wadah sebagai tempat pertemuan antara pembeli dengan penjual. ${ }^{13}$

Dunia bisnis kini lazim memanfaatkan jumlah pengguna media sosial yang mencapai jutaan di berbagai platform untuk memperkenalkan serta menarik perhatian calon costumer menggunakan produk mereka. Baik pebisnis senior maupun senior kini menggunakan media sosial sebagai sarana promosi.

\section{METODE PENELITIAN}

Sesuai dengan tujuan penelitian, jenis penelitian karya ilmiah ini menggunakan metode kualitatif dengan pendekatan deskriptif. Pendekatan deskriptif mencoba menjelaskan fenomena-fenomena sosial yang diteliti berupa kondisi, situasi yang berlangsung dalam hubungan sosial. Tujuan dari pendekatan deskriptif adalah memberikan gambaran secara menyeluruh dan mendalam mengenai fenomena yang diteliti, yang kemudian dianalisis dan diinterpertasikan. Pada kajian ini difokuskan menganalisis dan mengkaji penggunaan media sosial dan digital marketing untuk pengembangan bisnis yang dilakukan oleh Tanifund. Sehingga diharapkan dapat menghasilkan pemahaman komprehensif mengenai hal tersebut. ${ }^{14}$ Dalam temuan penelitian, penulis akan mengolah semua temuan penelitian dalam bentuk deskriptif. Penulisan hasil penelitian kualitatif dengan cara deskriptif sesuai dengan penjabaran untuk analisa fenomena sosial, terutama untuk penelitian yang mengkaji teks berita atau artikel.

Singarimbun dan Efendi dalam Atwar menjelaskan bahwa penelitian deskriptif merupakan cara yang cermat dalam menganalisa masalah sosial. Adapun tujuannya untuk mengembangkan konsep yang sudah ada dan mengumpulkan fakta-fakta. Bukan untuk menguji hipotesis. ${ }^{15}$ Di samping itu, penulis menganalisis bagaimana penggunaan media sosial sebagai strategi marketing bisnis di era digital yang dilakukan oleh Tanifund.

${ }^{13} \mathrm{https}$ //koinworks.com/blog/ketahui-tentang-peer-peer-lending/

${ }^{14}$ Ardial, Paradigma \& Model Penelitian Kom., (Jakarta: Bumi Aksara), 2014, hal. 249.

15 Atwar Bajari, Metode Penelitian Komunikasi; Prosedur, Tren, dan Etika, (Bandung: Simbioasa Media Rekatama), 2015, hal. 45. 


\section{HASIL DAN PEMBAHASAN}

\section{A. Tanifund: Agriculture Crowdlending Platform}

Tanifund masih terdengar asing bagi masyarakat. Namun pada akhir 2019, Tanifund telah menyalurkan pinjaman sebesar Rp. 86,8 miliar kepda 1500 petani. $^{16}$ Melalui Question and Answer (Q\&A) di website resminya, dijelaskan bahwa Tanifund adalah perusahaan finansial yang fokus pada pertanian, peternakan, dan perikanan. Berbagai pihak, baik kelompok maupun individu dapat mendanai para petani dengan manfaat bagi hasil menarik. Misi utama Tanifund adalah memberikan akses keuangan alternatif kepada petani, peternak dan nelayan Indonesia sehingga mereka dapat mengembangkan usahanya dan hidup lebih baik, sekaligus juga turut aktif dalam mengedukasi dan membina para petani, peternak dan nelayan. TaniFund merupakan PT Tani Fund Madani Indonesia, suatu Perseroan Terbatas (PT) yang didirikan berdasarkan hukum negara Republik Indonesia yang memiliki kegiatan usaha sebagai penyelenggara Layanan Pinjam Meminjam Uang Berbasis Teknologi Informasi dan telah terdaftar dan diawasi oleh Otoritas Jasa Keuangan.

TaniFund merupakan anak perusahaan dari TaniHub (Marketplace Produk Pertanian). TaniHub menghubungkan para petani dari berbagai daerah di Indonesia dengan para pelaku bisnis. Namun, petani di Indonesia banyak yang mengalami masalah utama berupa pembiayaan. Melihat masalah tersebut, TaniHub meluncurkan TaniFund dengan tujuan untuk memberikan pembiayaan bagi para petani di Indonesia. Dengan bantuan pembiayaan dari para founder, petani di Indonesia dapat mengembangkan pertaniannya. Selain itu, masyarakat Indonesia dapat ikut serta membantu meningkatkan perekonomian masyarakat.

Platform kreatif dan memberikan efek positif bagi masyarakat tentunya dikelola oleh orang-orang berkompeten di bidangnya. Adapun Advisor Tanifund terdiri dari J.W Saputro,P.Hd selaku Pendiri dan Dr. Rahmat Waluyanto, M.B.A, Selaku Wakil ketua dewan Komisioner Otoritas Jasa Keuangan (OJK) 2012-2017. Direktur Tanifund adalah Ivan Arie Sustiawan Sebelum menjabat sebagai direksi

${ }^{16}$ https://keuangan.kontan.co.id/news/tanifund-telah-salurkan-pinjaman-sebesar-rp-868miliar-kepada-1500-petani, diakses 26 Juni 2020. 
TaniFund, Ivan yang memperoleh gelar pendidikan akuntansi ini mendalami karirnya di bidang finansial dan industri ritel selama lebih dari 15 tahun.

Melalui pengalamannya, Ivan dipercayakan secara menyeluruh untuk bertanggungjawab terhadap perkembangan TaniFund dalam memajukan sektor finansial pertanian Indonesia. Duduk di kursi komisaris Pamitra Wineka, ia memperoleh gelar pendidikan Matematika di Institut Teknologi Bandung dan Master Ekonomi di Illinois University ini, dipercayakan untuk menjabat sebagai komisaris TaniFund, dengan kompetensi dan pemahaman industri yang impresif di bidang keuangan, terutama pengalamannya bekerja di World Bank dan institusi keuangan lainnya. Tanifund memiliki mitra dari para petani yang gigih dan ulet dalam usahanya. Sejak bergabung dengan TaniFund mereka dapat menanam dalam skala lebih besar dari sebelumnya. Mereka juga dapat memberdayakan para penduduk di sekitarnya sehingga pengangguran berkurang di desanya. ${ }^{17}$

\section{Gambar 1.2. Home Website Tanifund}

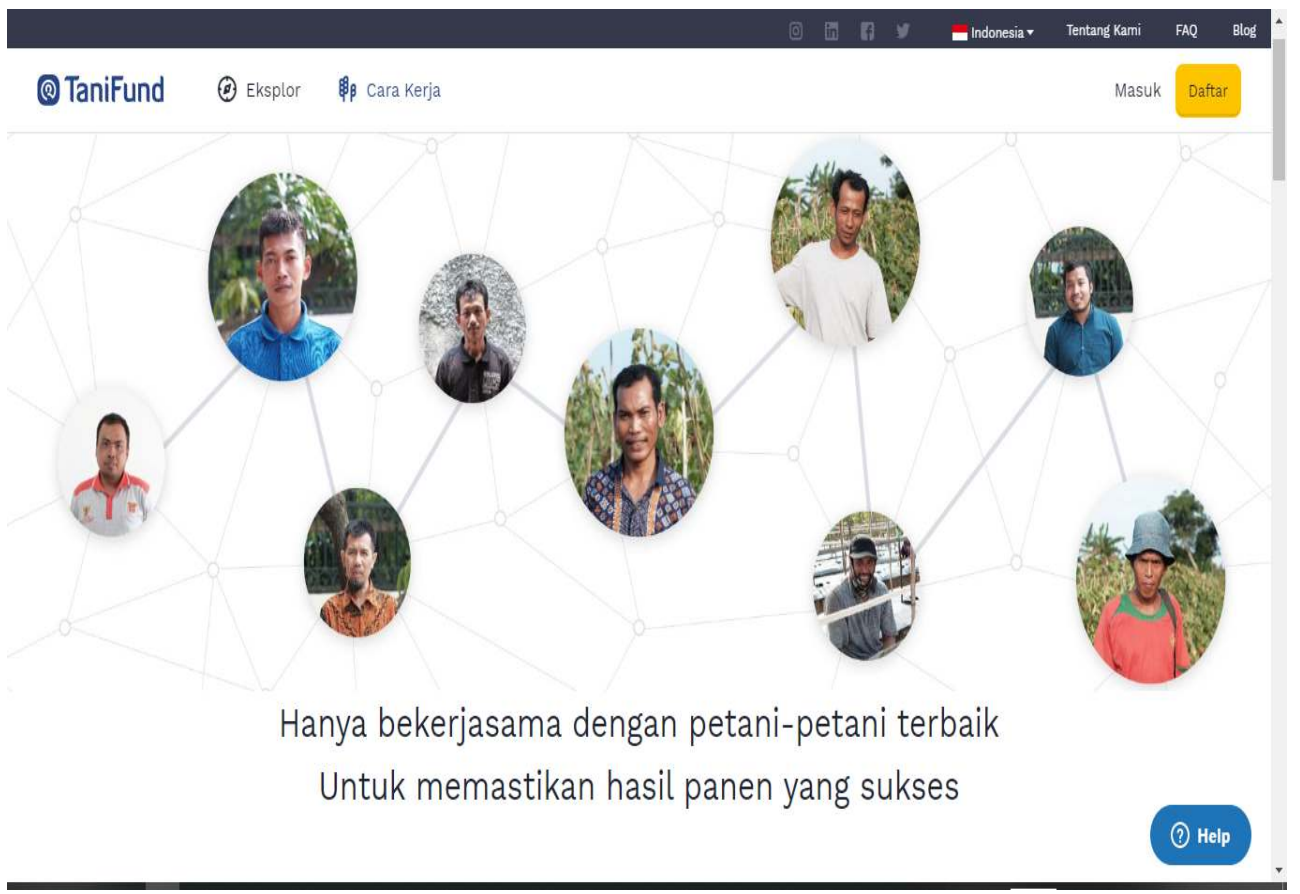

${ }^{17}$ https://tanifund.com/faq, diakses pada 24 Juni 2020 


\section{Gambar 1.3 Tanihub yang Menjadi Media Penjualan Hasil Tanifund}

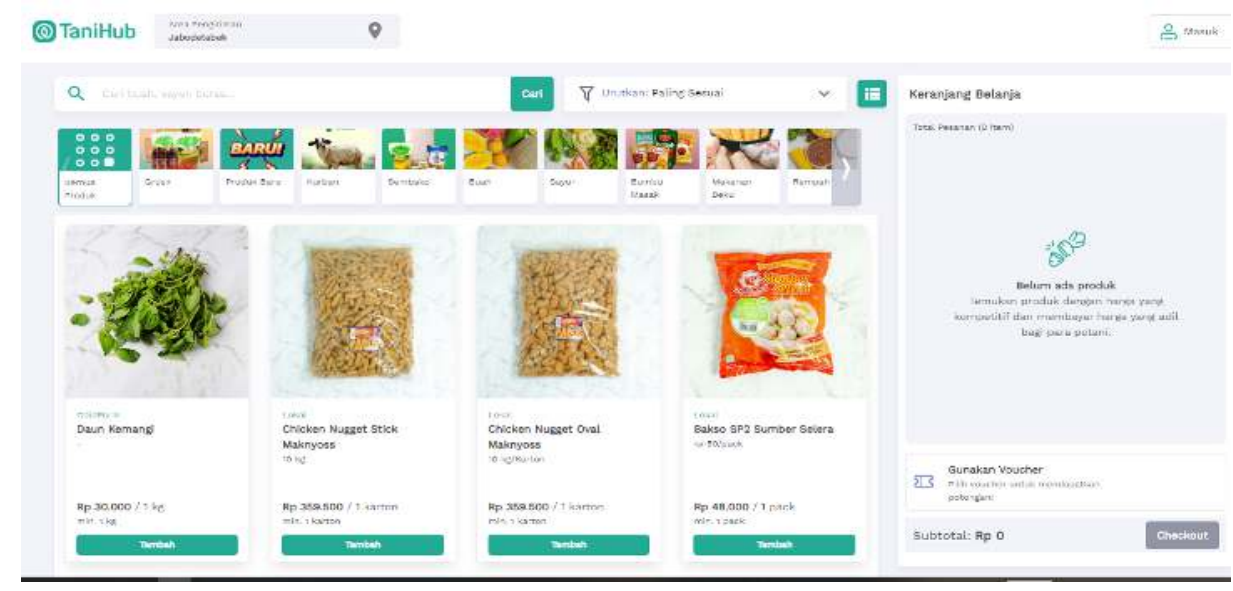

Di antara beberapa mitra Tanifund adalah Endang Gunawan, Ketua kelompok Tani Mandiri, Bogor. Zuhrul Anam, Ketua kelompok Pariqo Tani di Pandeglang, Saepulloh Ketua kelompok tani Alam Lestari Bandung serta Rahmat Suherman Ketua kelompok Sahabat Tani dari Bandung.

Tanifund Agriculture Crowdlending Platform menawarkan kepada semua orang maupun badan beberapa pilihan yaitu sebagai calon Pemberi Pinjaman, calon Penerima Pinjaman, Penerima Pinjaman, Pemberi Pinjaman. "Layanan TaniFund" adalah layanan pinjam meminjam uang berbasis teknologi informasi yang mempertemukan Pemberi Pinjaman dengan Penerima Pinjaman yang diselenggarakan oleh TaniFund.

\section{Gambar 1.4 Penawaran dari Tanifund}

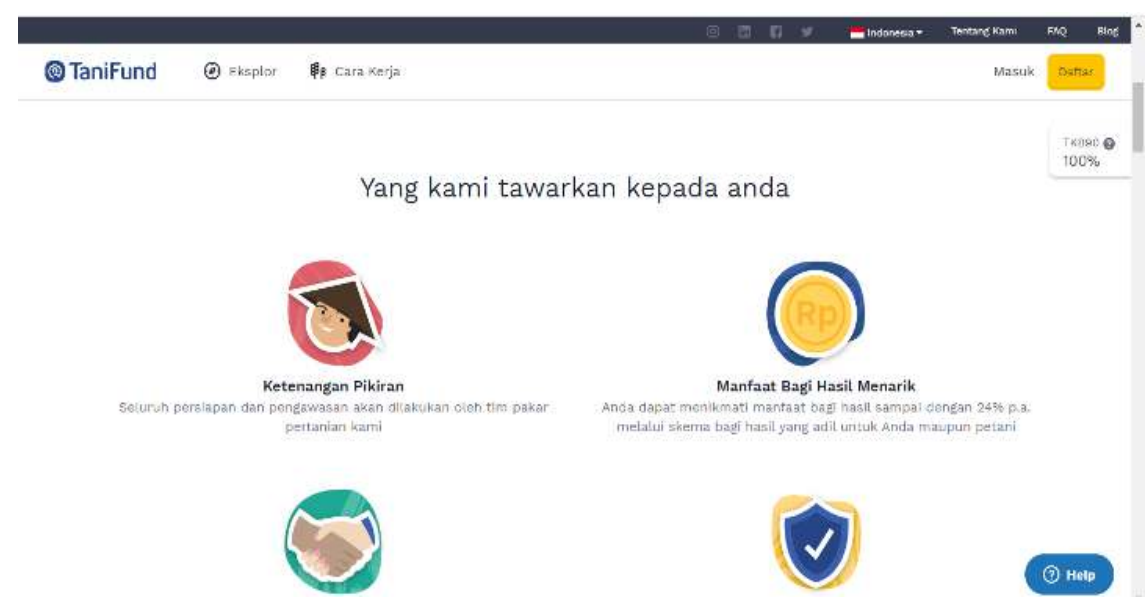


Sehubungan dengan Layanan TaniFund, TaniFund adalah penghubung antara Pemberi Pinjaman dan Penerima Pinjaman yang berperan sebagai penyedia, pengelola, dan pengatur transaksi pemberian fasilitas pinjaman antara Pemberi Pinjaman dan Penerima Pinjaman melalui Platform TaniFund. Transaksi pinjam meminjam antara Pemberi Pinjaman dan Penerima Pinjaman merupakan kesepakatan perdata antara Pemberi Pinjaman dengan Penerima Pinjaman, sehingga segala risiko yang timbul dari kesepakatan tersebut ditanggung sepenuhnya oleh masing-masing pihak. Risiko kredit atau gagal bayar ditanggung sepenuhnya oleh Pemberi Pinjaman. TaniFund berhak untuk melaksanakan prinsip mengenal nasabah (know your customer principle) dan uji kelayakan terhadap calon Pemberi Pinjaman dan calon Penerima Pinjaman. TaniFund dapat menghubungi anda, lembaga, perusahaan, atau individu terkait untuk mencari informasi, melakukan verifikasi dan konfirmasi informasi terkait Anda, termasuk namun tidak terbatas pada rekam jejak secara hukum dan keuangan Anda. ${ }^{18}$

\section{B. Analisis Strategi Bisnis Era Digital}

Aksesibilitas dan interaktivitas internet menghadirkan perubahan dramatis pada paradigma pemasasran konvensional. Internet mengubah cara origanisasi merancang, memproses, memproduksi, memasarkan hingga menyampaikan produk. Lingkup pemasaran yang semakin luas juga menuntut integrasi dan koordinasi antara departemen sistem informasi, pemasaran, layanan pelanggan dan departemen-departemen lainnya dalam organisasi. ${ }^{19}$ Dalam era e-bisnis, website berperan penting sebagai interface di antara banyak karyawan, perusahaan, antara perusahaan dengan pemasok dan konsumen. Misalnya, belanja online dapat mengeliminasi berbagai kendala ritel tradisional, seperti hambatan geografis, kendala waktu, kendala informasi dan kendala beralih pemasok. Secara garis besar, manfaat beralih ke e-business meliputi: ${ }^{20}$

a. Informasi manajerial yang lebih akurat dan epat, sehingga dapat membatu pengambilan keputusan secara lebih efektif dan efisien;

\footnotetext{
${ }^{18} \mathrm{https}$ ://tanifund.com/faq, diakses pada 24 Juni 2020

${ }^{19}$ Fandi Tjiptono dan Gregorius Chandra, Pemasaran Global konteks Offline dan, hal, 242.

${ }^{20}$ Fandi Tjiptono dan Gregorius Chandra, Pemasaran Global konteks Offline dan, hal, 243.
} 
b. Integrasi dengan pemasok dan jejaring distribusi secara lebioh baik dan real-time;

c. Kemitraan distribusi yang lebih baik;

d. Biaya transaksi lebih murah;

e. Pemahaman pasar lebih baik;

f. Cakupan geografis yang lebih luas.

Dalam pemanfaatan internet sebagai aktivitas bisnis dan pemasaran, terdapat setidaknya tiga aktivitas yang dapat difasilitasi secara efektif: aktivitas pemasaran informasional, fasilitasi relasi, dan pemasaran transaksional di internet.

\section{Tabel 1.1}

\section{Aktivitas Pemasaran Informasional, Fasilitasi Relasi dan Transaksional di Internet}

\begin{tabular}{|c|c|c|c|c|}
\hline No & $\begin{array}{c}\text { Aktivitas } \\
\text { pemasaran }\end{array}$ & $\begin{array}{c}\text { Informasional } \\
\text { (Akses informasi) }\end{array}$ & $\begin{array}{c}\text { Fasilitasi (Membangun } \\
\text { relasi) }\end{array}$ & $\begin{array}{c}\text { Transaksional } \\
\text { (Online } \\
\text { Exchange) }\end{array}$ \\
\hline 1. & $\begin{array}{l}\text { Layanan } \\
\text { Pelanggan }\end{array}$ & $\begin{array}{l}\text { Fasilitas pencarian } \\
\text { informasi } \\
\text { Fasilitas Browsing } \\
\text { FAQ (Frequently } \\
\text { Asked Questions) } \\
\text { Sejarah Perusahaan } \\
\text { Laporan keuangan }\end{array}$ & $\begin{array}{l}\text { Identifikasi personal } \\
\text { Komunikasi langsung (one- } \\
\text { to-one) } \\
\text { Layanan bantuan online }\end{array}$ & $\begin{array}{l}\text { Umpan balik } \\
\text { pelanggan } \\
\text { Apliksi atau } \\
\text { langganan online }\end{array}$ \\
\hline 2 & Produk & $\begin{array}{l}\text { Katalog Produk } \\
\text { Brosur perusahaan }\end{array}$ & $\begin{array}{l}\text { Informasi bernilai tambah } \\
\text { Bantuan tentang pilihan } \\
\text { produk }\end{array}$ & $\begin{array}{l}\text { Customization } \\
\text { Partisipasi dalam } \\
\text { desain produk }\end{array}$ \\
\hline 3. & Distribusi & $\begin{array}{l}\text { Informasi lokasi } \\
\text { Contact details }\end{array}$ & $\begin{array}{l}\text { Real time order processing } \\
\text { Keterlibatan mitra } \\
\text { pemenuhan yang dipercaya }\end{array}$ & $\begin{array}{l}\text { Pemesanan online } \\
\text { Pembayaran online } \\
\text { Distribusi online }\end{array}$ \\
\hline 4. & Harga & Informasi harga & $\begin{array}{l}\text { Kalkulasi biaya } \\
\text { Metered pricing } \\
\text { Online Quotes }\end{array}$ & $\begin{array}{l}\text { Dynamic pricing } \\
\text { Partisipasi } \\
\text { pelanggan } \\
\text { Lelang online }\end{array}$ \\
\hline
\end{tabular}




\begin{tabular}{|l|l|l|l|l|}
\hline 5. & Promosi & $\begin{array}{l}\text { Alamat situs di } \\
\text { komunikasi offline }\end{array}$ & $\begin{array}{l}\text { Hot links within site } \\
\text { Promosi online }\end{array}$ & $\begin{array}{l}\text { Partisipasi } \\
\text { pelanggan } \\
\text { (misalnya, iklan } \\
\text { interaktif) }\end{array}$ \\
& Periklanan online & $\begin{array}{l}\text { Links dengan perusahaan } \\
\text { lain }\end{array}$ & \\
& & Customizes promotions & \\
\hline
\end{tabular}

Sumber: Arnott dan Bridgewater, 2002

Melalui tabel di atas dapat diamati aktivitas pemasaran dalam bisnis online, pelanggan memiliki akses serta dapat berkomunikasi dengan lebih seluasa dengan produsen, dalam pemilihan produk dan distribusi, konsumen dapat terlibat aktif memberi masukan dan saran sebagaimana mitra. Demikian juga dalam bidang promosi, pelanggan ikut berpartisipasi aktif, tentunya hal tersebut berbeda dengan metode bisnis tradisonal.

Selain itu, semua ciri khas tersebut juga dimiliki oleh Tanifund selaku layanan pinjam meminjam uang berbasis teknologi informasi yang mempertemukan Pemberi Pinjaman dengan Penerima Pinjaman di bidang pertanian, peternakan dan perikanan. Dapat diamati pada website Tanifund, transpansi dimana angka total pinjaman, pinjaman tahunan berjalan, total pinjaman lunas hingga rata-rata pengembalian dapat dilihat oleh para founder, konsumen dan petani di website resmi Tanifund.com.

\section{Gambar 1.5. Transparansi Tanifund}

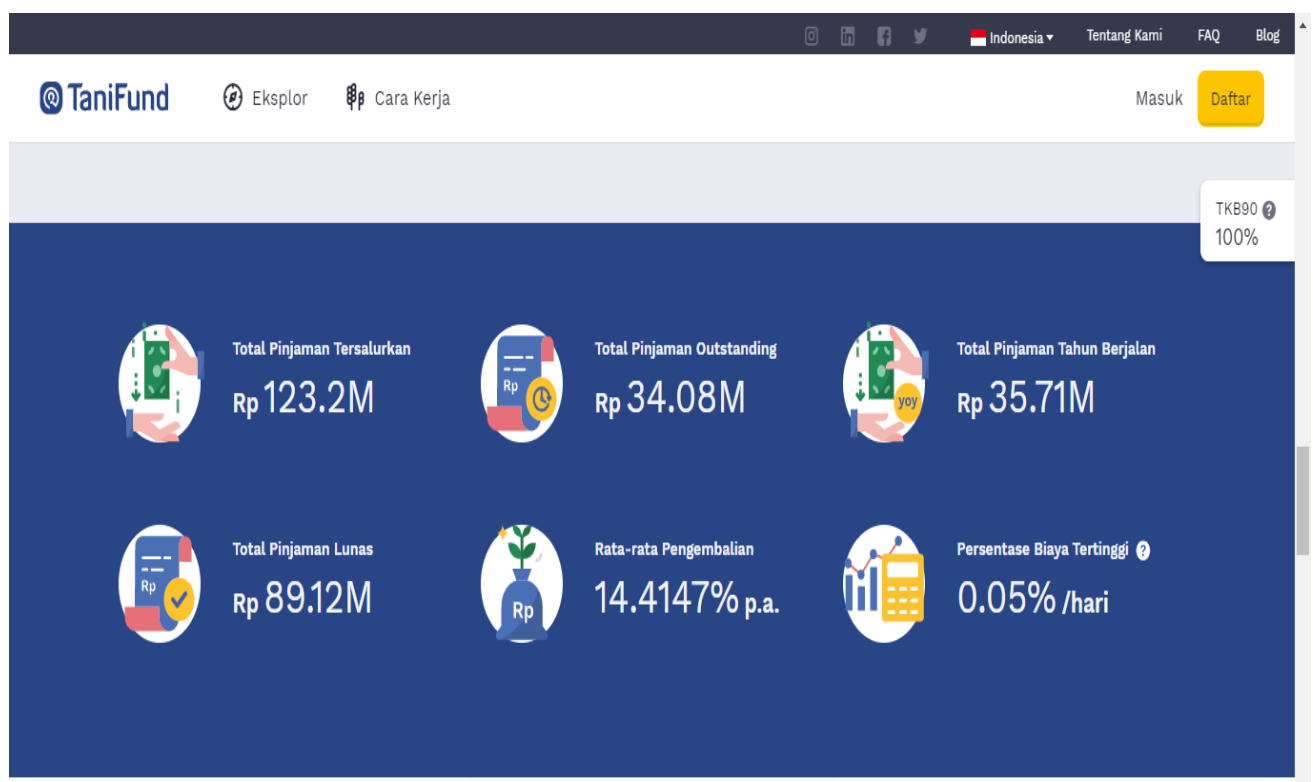


Peluang lain yang didapat dari internet antara lain:

a. Sumber informasi baru untuk infornasi pasar

b. Individualized customing marketing

c. Cara baru menjalin relasi dengan pelanggan, komunitas pelanggan, dan membangun citra merek (interactive marketing)

d. Peluang baru bagi distribusi dan komunikasi (e-commerce)

e. Berinteraksi dengan pelanggan via jejaring sosial

f. Sumber ide pengembangan produk-produk baru, dan sebagainya

Proses penyampaian (delivery) produk secara digital akan semakin berkembang dan diminati, meskipun demikian masih terdapat sejumlah tantangan besar yang masih perlu diantisipasi dan diatasi, di antaranya:

a. Ketersediaan dan kecepatan akses internet secara luas;

b. Infrastruktur dan regulasi menyangkut tarif telepon, jasa ISP dan $\mathrm{UU}$;

c. Isu menyangkut intellectual property rights, seperti hak cipta, paten, merek dagang dan proteksi data;

d. Isu privasi dan keamanan dalam transaksi online;

e. Isu perlindungan atas hak-hak konsumen;

f. Preferensi konsumen pada model bisnis tradisional (tatap muka), karena sebagian orang masih menganggap belanja adalah aktivitas sosial dan hiburan;

g. Kecepatan dan kemudahan pengiriman produk fisik;

h. Persoalan pengaturan penerimaan pajak pemerintah;

i. Kompleksitas upaya mewujudkan loyalitas pelanggan. ${ }^{21}$

Ketika dunia pertanian merambah ke ranah digital, persoalan seperti pada point (f) cenderung terjadi. Namun dengan model website yang menjanjikan serta metode transparansi, ditambah dengan penggunaan media sosial sebagai sarana promosi, hal tersebut dapat diminimalisir.

TaniFund akan melaksanan proses pengumpulan dana pinjaman (crowdfunding) selama paling lambat 30 (tiga puluh) hari yang dapat diperpanjang

${ }^{21}$ Fandi Tjiptono dan Gregorius Chandra, Pemasaran global, konteks online dan offline, (Yogyakarta:UPP STIM YKPN), 2012, hal 243 
oleh TaniFund sesuai kebutuhan untuk mengumpulkan dana fasilitas pinjaman yang diajukan oleh Penerima Pinjaman. Apabila hasil proses crowdfunding tidak mencapai jumlah pinjaman yang diajukan oleh Penerima Pinjaman, Penerima Pinjaman setuju untuk meminjam sejumlah dana yang terkumpul dari proses crowfunding. TaniFund berhak memperoleh komisi sebesar 2\% (dua persen) dan biaya layanan yang termasuk namun tidak terbatas pada biaya asuransi sebesar $1 \%$ (satu persen) dari suku bunga yang mana biaya-biaya tersebut akan dibebankan kepada Penerima Pinjaman untuk setiap pinjaman.

Melalui TaniFund, para pemodal dapat menikmati pertumbuhan dari dana yang disalurkan sementara juga membantu para petani, peternak dan nelayan mendapatkan permodalan yang diperlukan untuk mengembangkan usahanya. Hal tersebut merupakan solusi baik untuk semua pihak. TaniFund unik karena Tanifund berpartner dengan TaniHub untuk menyerap hasil panen dari para pelaku budidaya, sehingga memiliki jaminan pasar. TaniHub merupakan ecommerce pertanian digital dengan ratusan ribu pembeli yang terdiri dari pasar tradisional, pasar modern, industri, restoran, dan katering. TaniHub juga memberikan informasi dan rekomendasi kepada TaniFund mengenai produk apa yang sedang tinggi permintaannya namun memiliki suplai yang tidak konsisten. ${ }^{22}$

\section{Gambar 1. 6. Program Budidaya yang Ditawarkan}

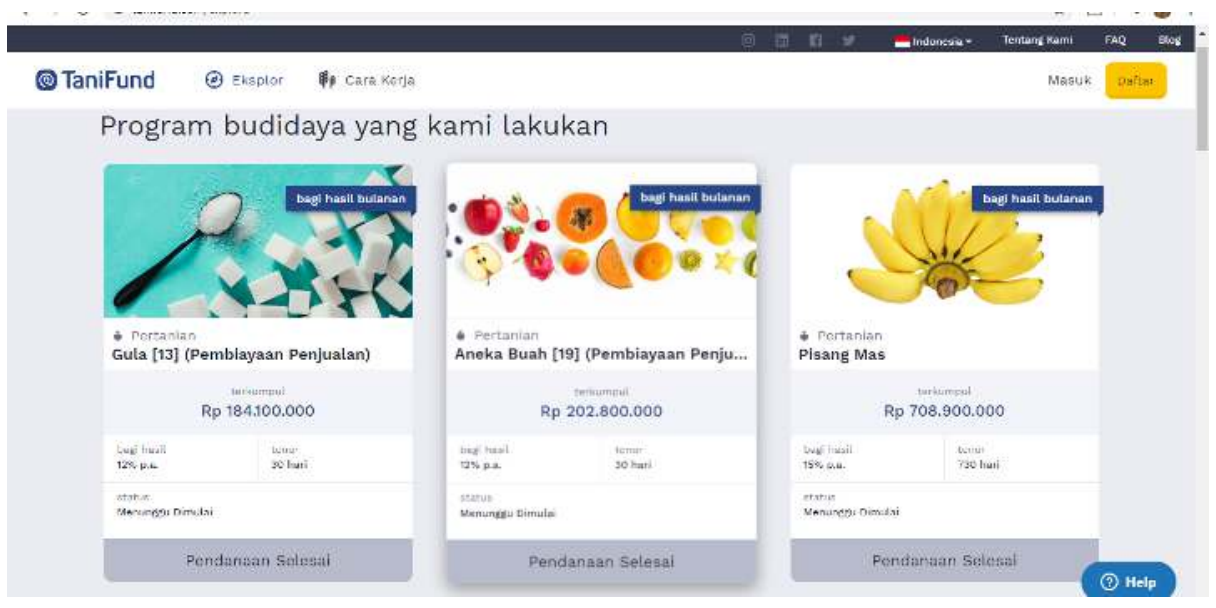

Pada gambar di atas terlihat beberapa pilihan pembiayaan dan jenis pembiayaan yang dapat dipilih oleh para calon peminjam atau pemberi modal.

${ }^{22} \mathrm{https}$ //tanifund.com/faq, diakses pada 24 Juni 2020 
Mulai dari pembiayaan aneka buah, gula, Pisang Mas, aneka Berry, aneka bahan pangan, pengembangan/pembiakan kambing, Jahe Merah, Kentang Granola, Jamur Tiram, Jagung Silage, Ayam Karkas beku, Ubi Cilembu dan lain sebagainya. Pada gambar jelas memperlihatkan jumlah uang yang terkumpul per jenis budidaya, beserta bagi hasil yang ditawarkan, misalnya bagi hasil bulanan untuk pembiayaan kangka pendek ataupun tahunan untuk jangka panjang. Tanifund juga mengedepankan transparansi jumlah pendaan dan proyek yang sedang berlangsung, telah berlangsung, sistem bagi hasil bulanan, pyoyek jangka panjang atau pun jangka pendek, semuanya tersedia di dalam prospectus.

Tanifund menawarkan berdapat jenis pembiayaan bagi hasil (profit sharing) dan pengembalian tetap (fixed repayment). Pembiayaan bagi hasil umumnya memiliki persentase imbal hasil yang dapat bervariasi pada setiap program budidaya, dengan resiko yang terbagi antar setiap pihak terkait. Untuk pengembalian tetap memiliki persentase yang umumnya lebih kecil dibandingkan dengan bagi hasil, namun dengan tingkat resiko yang lebih rendah. Skema bagi hasil dapat bervariasi bergantung pada program budidayanya. Namun, skema paling umum yang kami lakukan adalah 40\% untuk lender, 40\% untuk penggarap program budidaya, dan 20\% untuk TaniFund. Persentase bagi hasil yang ditampilkan pada program dengan pembiayaan jenis ini merupakan kisaran estimasi dari konservatif hingga optimis, yang perhitungannya menggunakan perhitungan rata-rata persentase bagi hasil per tahun yang dihitung dari arus kas setiap tahun pada program terkait. Pada setiap jenis pembiayaan, tanifund menyertakan prospectus untuk dipelajari oleh calon founder.

\section{Gambar 1.7. Transparansi sekaligus Prospektus}

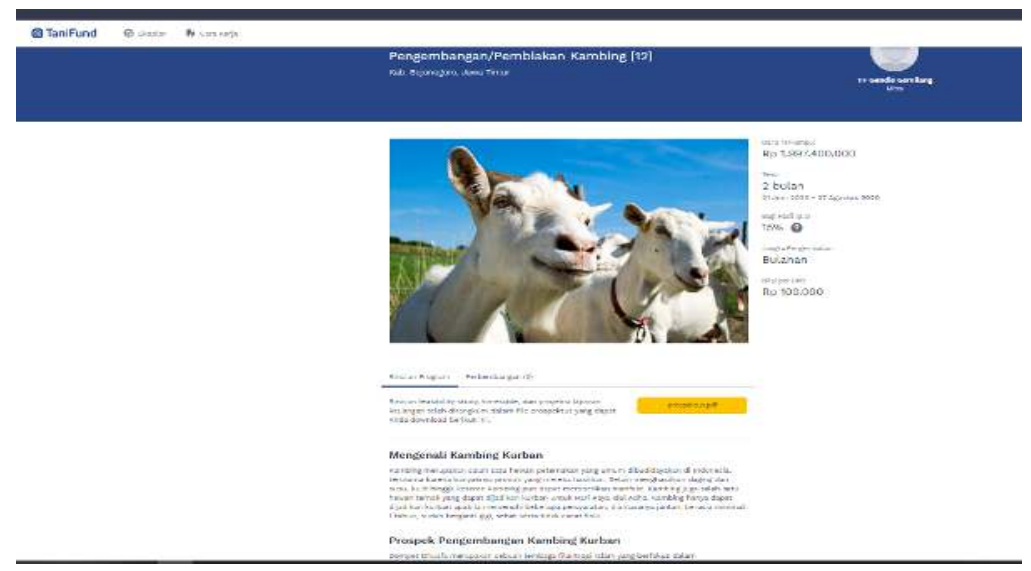


Berdasarkan uraian dari website resmi Tanifund, untuk skema Pembiayaan Tetap: Program dengan pembiayaan tetap memiliki presentase manfaat bagi hasil tidak berubah, dengan perhitungan menggunakan manfaat bagi hasil simpel per tahun: presentase manfaat bagi hasil = jumlah pengembalian / pokok / jumlah pembayaran x $12 \times 100$. Setiap program budidaya mempunyai jangka waktu yang berbeda-beda. Budidaya sayuran akan dilakukan dalam waktu yang relatif lebih singkat dibandingkan dengan budidaya buah-buahan. Uang akan dikembalikan beserta bagi hasilnya jika: Jangka waktu pembagian manfaat bagi hasil dapat berupa bulanan atau tahunan sesuai yang tertera pada program terkait. Sedangkan pengembalian modal/pokok baru dilakukan pada masa periode budidaya berakhir. Jika rugi/gagal panen: TaniFund berkolaborasi dengan perusahaan asuransi yang menyediakan asuransi pertanian jika terjadi gagal panen sehingga tingkat resiko untuk pemodal dapat diminimalisir. Tanifud juga telah memberi peringatan sejak awal bahwa program budidaya TaniFund memiliki resiko layaknya produk P2P lending pada umumnya. Banyak hal yang berada di luar kendali TaniFund sehingga potensi resiko selalu ada. Pererta tidak dapat membatalkan partisipasinya. Dalam program yang sedang berlangsung. Ketika mendaftar untuk berpartisipasi pada suatu program budidaya, dana akan dikunci sebagai komitment para pemodal kepada pelaku budidaya.

Dana pokok tersebut baru dapat dikembalikan pada akhir masa program budidaya. Dari Q\&A juga diketahui bagaimana metode Tanifund menyeleksi pelaku budidaya Para pelaku budidaya di TaniFund merupakan petani, peternak, dan nelayan yang telah diseleksi dan di rekomendasi oleh TaniHub. Para petani, peternak dan nelayan tersebut diwajibkan memiliki rekam jejak baik dalam bertransaksi di TaniHub, atau di tempat lain, serta memiliki produk yang berkualitas sebelum dapat menjadi pelaku budidaya di TaniFund. Resiko adalah sesuatu yang tidak dapat dihindarkan dalam bisnis apa pun. Namun pihak Tanifund akan melakukan pengelolaan dan pengawasan sebaik-baiknya untuk meminimalisasi segala resiko yang dapat terjadi. Selain itu, Tanifund juga secara berkala melakukan edukasi dan pelatihan kepada para pelaku budidaya.

Untuk media sosial, Tanifund sendiri aktif membagikan cerita dari para founder maupun petani serta berbagai pihak yang bekerjasama dengan Tanihub. 
Misalnya postingan di Instagram pada 19 Juni 2020 mengenai Cerita Peternak Dompet DHuafa. Tanifund juga aktif memberikan edukasi seperti pada postingan di Instagram mengenai 'Memahami Proses Pendanaan petani di Luar Bank oleh Edison Tobing, Direktur Tanifund. Selain itu melalui media sosial, Tanifund aktif memberikan tips dan trik mengenai pertanian, peternakan dan perikanan, tentu saja dengan bentuk infografis yang unik dan kreatif.

\section{Gambar 1.8. Instagram Tanifund}

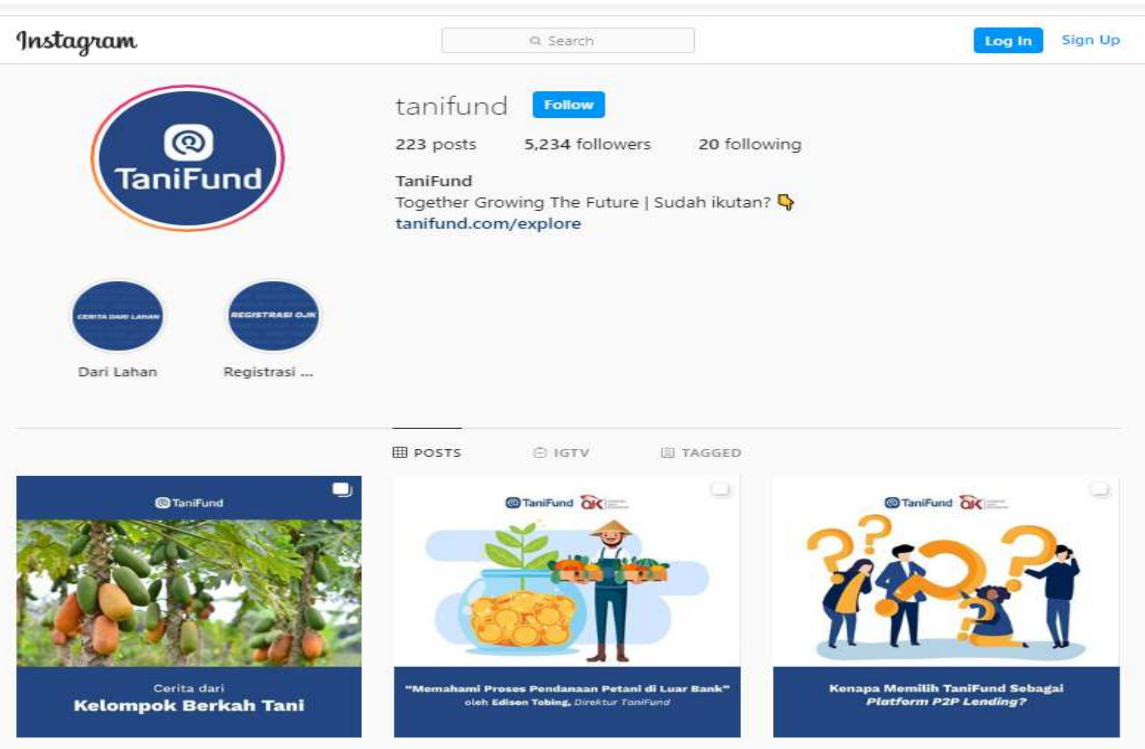

Gambar 1.9 Twitter Tanifund

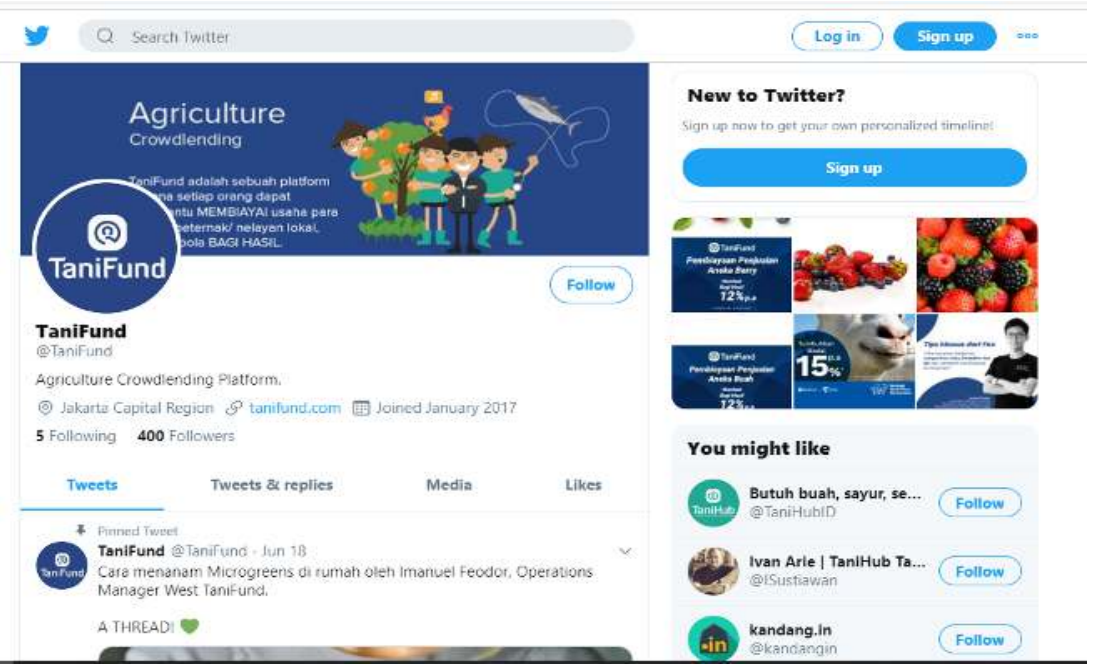




\section{Gambar 1.10. Facebook Tanifund}

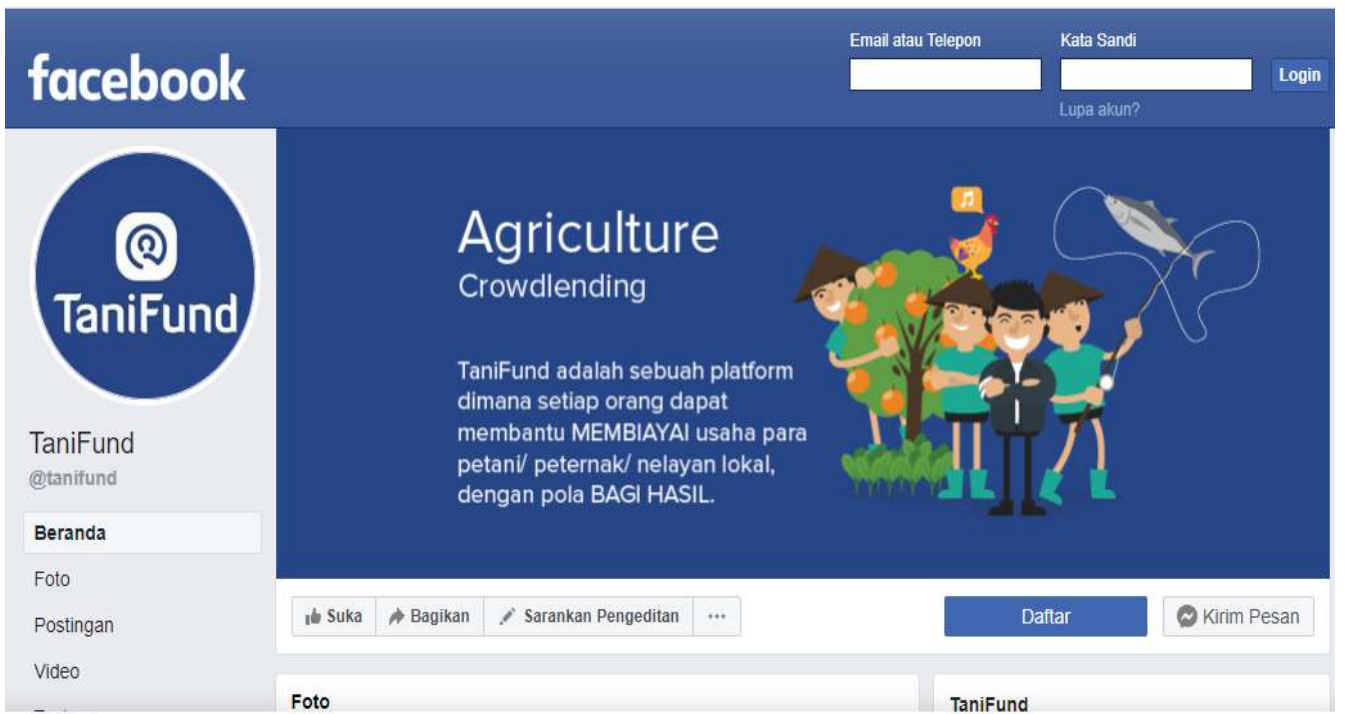

Gambar 1.11 Youtube berisikan Informasi mengenai Tanifund

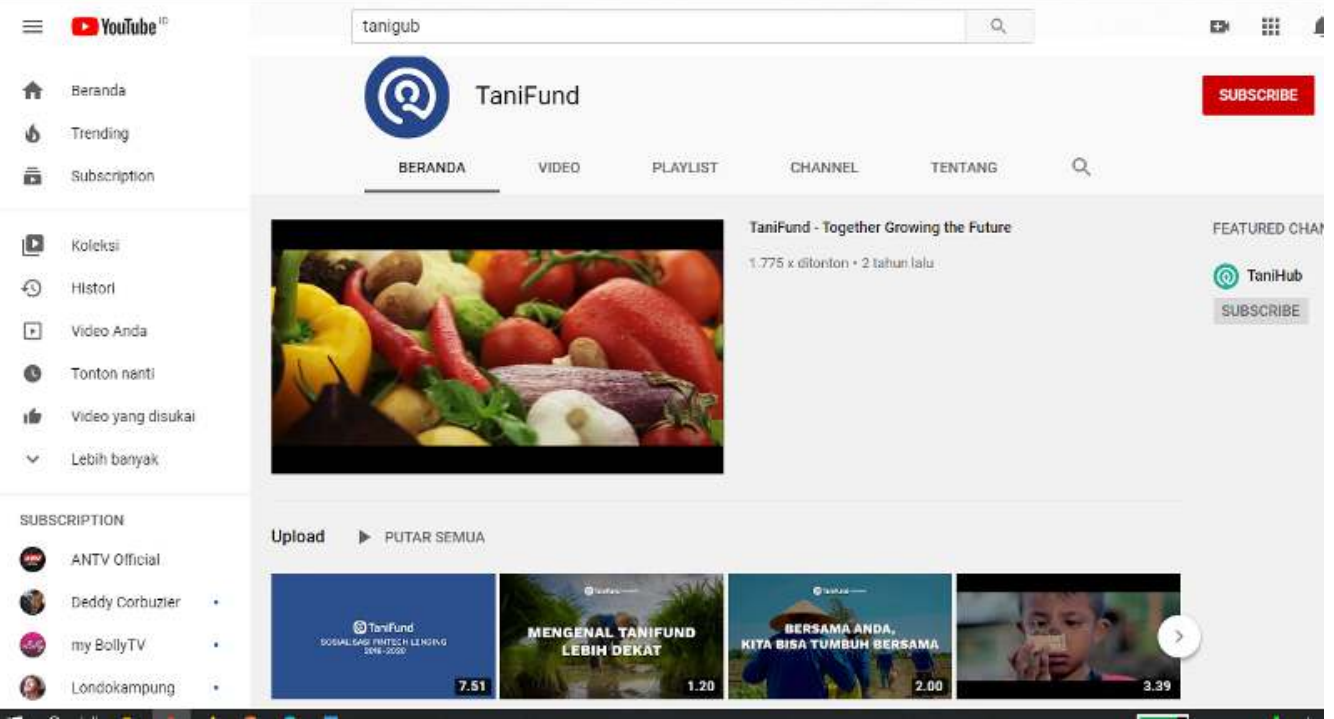

Dari beberapa platform media sosial yang digunakan oleh Tanifund terlihat dengan jelas bahwa Tanifund menggunakan berbagai jenis media sosial untuk mempromosikan, sekaligus mengembangkan bisnis Agriculture Crowdlending tersebut, meskipun jika diamati lebih lanjut promosi menggunakan media sosial belum dilaksanakan secara maksimal dan belum memiliki jumlah pengikut (followers) hingga ratusan bahkan jutaan. Misalnya Instagram Tanifund baru memiliki 5.236 followers, namun Tanifund termasuk aktif dalam mengunggah 
berbagai informasi di Instagram mereka, terbukti mereka memiliki 223 postingan hingga 27 Juni 2020. Di Facebook, juga aktif membagikan informasi mengenai pertanian, perikanan dan peternakan, termasuk tips dan trik serta mempromosikan program yang mereka miliki. Kemudian Tanifund juga memiliki Twitter yang memiliki 400 followers, sedangkan di kanal Youtube, Tanifund memiliki 10 postingan dengan kunjungan terbanyak dapat dilihat pada judul postingan yang diunggah dua bulan yang lalu "Tekad, Kisah Inspiratif Petani Tanifund" telah ditonton 3000 kali. Jika postingan rutin diunggah, maka akan meningkatkan jumlah subscriber maupun followers Tanifund. Hal tersebut juga akan berpengaruh pada peningkatan jumlah share dan jumlah masyarakat yang menerima informasi mengenai Tanifund. Media sosial juga membutuhkan treatment khusus agar dapat memaksimalkan tujuan dari penggunaan media sosial itu sendiri. Misalnya mengubahnya menjadi akun bisnis, serta menggunakan influencer untuk mempromosikan Instagram agar produk yang ditawarkan menjangkau lebih banyak kalangan. Sehingga jumlah pendanaan yang dilakukan dapat mencapai jumlah maksimal.

Penyebaran (share) merupakan karakter lainnya dari media sosial. Medium tidak hanya menghasilkan konten yang dibangun dari dan dikonsumsi oleh penggunanya, tetapi juga didistribusikan sekaligus dikembangkan oleh penggunanya (benkler, 2020: Cross, 2011). Praktik ini merupakan ciri khas dari media sosial yang menunjukkan bahwa khalayak aktif menyebarkan konten sekaligus mengambangkannya. Pengembangan yang dimaksud dapat berupa data atau fakta terbaru dan komentar ataupun opini. ${ }^{23}$

\section{KESIMPULAN}

Kegiatan bisnis yang mulanya merupakan interaksi antara para pengusaha dan konsumen dengan sistem tradisional, dituntut mengikuti perkembangan bisnis di era digital. Termasuk hadirnya berbagai jenis platform media sosial, hal tersebut berpengaruh terhadap metode bisnis. Kini promosi serta pengembangan bisnis lazim menggunakan media sosial untuk menjangkau masyarakat luas. Hal tersebut dapat dilihat dari metode yang digunakan oleh Tanifund, yaitu platrofm pendanaan

${ }^{23}$ Rulli Nasrullah, Media Sosial Perspektif Komunikasi, Budaya dan, ... hal 24 
finansial yang fokus pada pertanian, peternakan, dan perikanan.

Tanifund menggunakan website serta beberapa media sosial untuk promosi dan pengembangan usahanya, antara lain Facebook, Instagram, Twitter, serta kanal Youtube. Namun jumlah pengikut pada setiap jenis platform media sosial Tanifund belum mencapai jumlah signifikan, sehingga masih diperlukan Langkah perbaikan untuk memperkenalkan Tanifund kepada masyarakat luas. Misalnya melakukan treatment khusus agar dapat memaksimalkan tujuan dari penggunaan media sosial itu sendiri. Misalnya mengubahnya menjadi akun bisnis, serta menggunakan influencer untuk mempromosikan Instagram agar produk yang ditawarkan menjangkau lebih banyak kalangan.

\section{DAFTAR PUSTAKA}

\section{Buku}

Amir Effendi Siregar, Mengawal Demokratisasi Media, Menolak Konsentrasi Membangun Keberagaman, (Jakarta: TIFA), 2014

Aunur Rofiq, Pertumbuhan Ekonomi dan Kemiskinan Kebijakan dan Tantangan Masa Depan, (Jakarta: Republika), 2014

Fandi Tjiptono dan Gregorius Chandra, Pemasaran Global Konteks Offline dan Online, (Yogyakarta: UPP STIM YKPN), 2012

Ignatius Haryanto, Jurnalisme Era Digital Tantangan Industri Media Abad 2, (Jakarta: Kompas Media Nusantara), 2014

Junaidi, Pemanfaatan Instagram Sebagai Media Dakwah di Kalangan Mahasiswa Kabupaten Aceh Barat, (Meulaboh: P3MSTAINTDM), 2019

Mohammad Hidayat, an Introduction to The Sharia Economic, (Jawa Timur: Zikrul Hakim), 2010

Rulli Nasrullah. Media Sosial Perspektif Komunikasi, Budaya dan Sosioteknologi, (Bandung: Simbiosa Rekatama Media), 2016

Sofjan Assauri, Manajemen Pemasaran, Dasar Konsep dan Strategi (Jakarta: Raja Grafindo Persada), 2007

William L Rivers, dkk, Media Massa dan Masyarakat Modern, (Jakarta: Kencana Prenada Media Group), 2008

\section{Akses daring}

https://datareportal.com/reports/digital-2020-indonesia diakses pada 26 Juni 2020 https://wearesocial.com/blog/2020/01/digital-2020-3-8-billion-people-usesocial-media, diakses 26 Juni 2020 
https://keuangan.kontan.co.id/news/tanifund-telah-salurkan-pinjamansebesar-rp-868-miliar-kepada-1500-petani, diakses 26 Juni 2020

https://tanifund.com/ diakses pada 24 Juni 2020

https://tanifund.com/faq, diakses pada 24 Juni 2020

https://koinworks.com/blog/ketahui-tentang-peer-peer-lending/ 